\title{
Democracy, Secularization, and Parliamentarism in the Muslim East: The History of 100th Anniversary of Reforms
}

\section{First Democracy and Parliamentarism in the East}

On May 27, 1918, the members of the Muslim Faction, i.e., of the Transcaucasian Muslim Council (Transcaucasian Muslim Parliament), held a separate meeting and decided to declare the independence of Azerbaijan. To this end, the Transcaucasian Muslim Council has declared itself the Azerbaijani National Council ${ }^{1}$, or rather the Parliament of Azerbaijan. Thus, the first parliament in the history of Azerbaijan emerged, and the foundation of the first parliamentary republic was laid. At that meeting, the Presidium and the Chairman of the National Council of Azerbaijan were elected. M. Rasulzade became the chairman of the National Council. A historic meeting of the National Council of Azerbaijan chaired by Hasan bey Aghayev was held on May 28. At the meeting, the National Council decided to establish the independent the Azerbaijan Democratic Republic (ADR) in the South-Eastern Caucasus. The ADR adopted the first normative legal act/independence act - Declaration of Independence on May 28, 19182. The National Council decided to establish the first interim government at the meeting. The National Council and the first government moved from Tbilisi to Ganja on June 16, 1918, and continued its activity from November 16 to December 7 in Baku until the opening of the first parliament.

It is clear from the archives of the ADR that, after the completion of the organizational work, the opening of the parliament was scheduled for December 3, 1918. However, the first session of the parliament was held on December 7. Alimardan bey Topchubashov was elected chairman and Dr. Hasanbay Agayev the first deputy chairman of the Parliament. Aghayev chaired the parliament as Topchubashov was in Istanbul at that time ${ }^{3}$.

For the first time in the entire Turkic-Muslim world, and generally in the whole East, a Declaration of Independence was a sign of the establishment of a democratic republic governance method, a parliamentary republic in

\footnotetext{
${ }^{1}$ M. Gasimly, The First Democratic Republic in the Muslim East, "Xalq" [Khalg] newspaper, 25.05.2016, http://www.xalqqazeti.com/az/news/politics/71716, retrieved 5.09.2019.

${ }^{2}$ Y. Mahmudov, Encyclopedia of People's Republic of Azerbaijan, Vol. I, Lider Nashriyyat 2004, p. 28.

${ }^{3}$ Ibidem, pp. 28-30.
} 
Azerbaijan. The ADR granted equality, liberty and peaceful life without discrimination for nationality, religion, sect, class or gender of all citizens living in its territory proclaiming the Declaration of Independence ${ }^{4}$.

Thus, our statehood traditions revived in the northern lands of Azerbaijan again, this time in the form of a parliamentary republic, in a very complicated historical situation that emerged during the First World War and the overthrow of the Romanov autocracy.

The ADR has left a deep and rich mark on the history of Azerbaijan's statehood, especially in the history of parliament culture, by realizing its independent state-building experience, adopting legislative acts and decisions during its activity.

Our history of parliamentarism is divided into two periods during the ADR: the first period - from May 27 to November 19, 1918. Four Muslim parties - "Musavat" and a group of democratic neutralizers within it, "Muslim Socialist Bloc", "Muslim in Russia" ("Ittihad"), "Hummat" (Menshevik) parties consisting of $44 \mathrm{MPs}^{5}$ - represented the parliament acting under the name of the National Council of Azerbaijan during this six-month period.

Our first Parliament proclaimed the independence of Azerbaijan on May 28, 1918 , took over the country's leadership, and adopted the Declaration of Independence. As the most brilliant legal document in the history of democracy and parliamentary traditions of Azerbaijan, the Declaration of Independence retains its historical and practical significance. A total of 10 meetings were held including the Constituent Assembly of the Azerbaijani Parliament during the National Council. The first meeting was held on May 27, 1918, in Tbilisi, and the last meeting was on November 19, 1918, in Baku. The National Council of Azerbaijan was established on May 27, temporarily suspended its activities on June 17, and gave the legislative and executive powers to the interim government with the condition to summon Constituent Assembly not later than six months. After the Government of the ADR moved to Baku on September 17, 1918, the National Council of Azerbaijan restored its activity on November 16. On November 19 the National Council of Azerbaijan adopted a law on calling the Constituent Assembly, expanded Parliament of Azerbaijan on December 3 of the same year and suspended its activities. Thus, the Azerbaijani Parliament operated in Tbilisi, Ganja, and Baku during this period of its activity, i.e., during the National Council'.

${ }^{4}$ Azarbaycan Xalq Cümhuriyyati dövründə hayata keçirilan sosial siyasat, 6.04.2018, http://www.azerbaijan-news.az/view-143712/Az\%C9\%99rbaycan-Xalq-C\%C3\%BCmhuriyy\%C9\%99ti-d\%C3\%B6vr\%C3\%BCnd\%C9\%99-h\%C9\%99yata-ke\%C3\%A7iril\%C9\%99n-sosial-siyas\%C9\%99t, retrieved 5.09.2019.

${ }^{5} \mathrm{M}$. Gasimly, op. cit.

${ }^{6}$ Y. Mahmudov, Encyclopedia of People's Republic of Azerbaijan..., pp. 28-30. 
The second period, or the period of the Baku, in the history of the ADR, lasted only 17 months, from December 7, 1918, to April 27, 1920. The first meeting was on December 7, 1918, the last meeting was held on April 27, 1920. In all these meetings, the Parliament of the ADR, by following the principles set out in the Declaration of Independence, and considering the specific historical conditions, adopted fundamental laws and decisions aiming: to ensure the country's territorial integrity and to maintain its independence; to create the most modern legal-democratic state where human rights and freedoms are fully respected. All these laws and decisions, ultimately, focused on the formation of three branches - the legislative, executive and judicial authorities - of government.

The Azerbaijani Parliament, operating in a very complicated internal and international historical context where the struggle of the great powers to divide the world in the First World War entered the crucial stage, dedicated the most significant portion of its activity to the maintenance of state independence and army building.

Even though it operated under very complicated conditions, the Government and the Parliament of the Republic kept its focus on the development of science, education and public education, and health care. Schools, gymnasiums, girls' schools, kindergartens, and libraries were opened in the whole country, short-term teacher courses, hospitals, and medical assistant points were established in rural areas, and a fight against infectious diseases was put into action. From this point of view, it is necessary to note the law adopted by Parliament on the establishment of the Baku State University on September 1, 1919. The opening of the National University was a significant historical service of Republican figures to the nation ${ }^{7}$.

The traditions of parliamentarism in Azerbaijan were being increasingly strengthened and developed, and the most modern parliamentary culture was being formed during the republic. At the time of the existence of the ADR, 155 parliamentary sessions were held, of which 10 were during the National Council of Azerbaijan (May 27 - November 19, 1918), and 145 during the period of the Parliament of Azerbaijan (December 7, 1918 - April 27, 1920).

The law on the establishment of Parliament envisaged that the Parliament would consist of 120 members. Even though there were 21 seats for Armenian and ten seats for Russian representatives according to the total number of the Azerbaijani population, they did not participate in the opening of the first meeting of the Azerbaijani Parliament. The Russian National Council participated

\footnotetext{
${ }^{7}$ Idem, Azarbaycan Xalq Cümhuriyyati Türk - Íslam dünyasında ilk demokratik, hüquqi və dünyəvi dövlat idi, “Xalq” newspaper, 28.05.2016, № 115, pp. 6-7.

${ }^{8}$ Idem, Encyclopedia of People’s Republic of Azerbaijan..., pp. 32-37.
} 
in the work of the Parliament from January 31, 1919, Armenians from the February of the same year?.

By the end of 1919, a total of 96 MPs represented 11 different party factions and groups in the Parliament. The activity of the Parliament was regulated by the "Instruction of Azerbaijani Parliament", which played a role of its Charter directly. From the first day based on the "Instruction of Azerbaijani Parliament" parliamentary sessions were held only in Azerbaijani. However, representatives of other nations could speak Russian.

More than 270 bills were drafted for the parliament, 230 of which were accepted. Members of 11 factions and groups participated in the preparation, discussion and approval of the laws of parliament. There were 11 commissions in the Parliament of the $\mathrm{ADR}^{10}$.

\section{Historical Background of "Women's Rights Movement" in the East and the Islamic World by Granting the Right to Elect and to Be Elected to Women for the First Time}

One of the intellectuals of the period, Ahmed Aghaoghlu, fought for the thought of the state based on the nation. He assimilated the state view that protects the rights and freedoms of the individual. Aghaoghlu states that two critical issues must be solved in order to ensure the salvation and progress of Islamic communities: the woman question and the issue of the alphabet. Aghaoghlu's views developed in Azerbaijan where he grew up and in Europe where he studied ${ }^{11}$.

The right ensuring democratic traditions to participate in elections was given to women along with men during the activity of the Azerbaijan Democratic Republic (ADR) in 1919 still seemed far away for the European states at that time $^{12}$. After Azerbaijan restored its independence in 1991, the role of women in the development of civil society and the building of an independent state began to increase. Today, based on the orders and decrees signed by the head of the country, a legislative framework for the protection of Azerbaijani women's rights has been established and operates in full.

The right to vote is a fundamental human right, through which the people exercise their sovereign rights. Recognition of the equal rights of all citizens

\footnotetext{
${ }^{9}$ Ibidem, p. 36.

${ }^{10}$ Z. Jskərov, Müsalman Şərqinin va Azarbaycanın 100 yaşlı parlamenti, 19.09.2018, http:// www.azerbaijan-news.az/view-154319/M\%C3\%BCs\%C9\%991man-\%C5\%9E\%C9\%99rqininv\%C9\%99-Az\%C9\%99rbaycan\%C4\%B1n-100-ya\%C5\%9Fl\%C4\%B1-parlamenti, retrieved 7.09.2019.

${ }^{11} \mathrm{G}$. Akalin, Ahmed Aghaoghlu in Turkish thought and political life, Baku 2004, p. 164.

${ }^{12}$ C. Nəsirov, Azarbaycan Xalq Cümhuriyyati dövlat quruculuğunun zangin hüquqi bazasını yaratmışdır, 30.03.2018, http://barassociation.az/frompress/63, retrieved 8.09.2019.
} 
and the right of women to vote before many European countries existed in Azerbaijan during the ADR.

The educated women in the Republican era were mainly engaged in culturalenlightenment, in social and public spheres. These women, who placed the mission of enlightenment at the root of both pedagogy and public activism, were never behind the men of the time. The reason was the right policy pursued by the Government of the Republic in the direction of women's issues and women's rights. For the first time in the East, women were given the right to vote. New girls' schools were opened, and women were trained for society as ready human resources. It is precisely these steps that increased the role of women in society ${ }^{13}$.

The creators of our national press bravely promoted the issue of women, as expressed by Hassan Bey Zardabi in the "Ekinchi" newspaper which had great importance in the development of knowledge, at the political and cultural levels, of the nation in their newspapers and magazines in the era of ignorance.

Holding a glorious place in the history of our national press the first combative body of our independent state, "Azerbaijan" newspaper started to light up the lives, freedoms and prosperity paths of our women as a beacon. "Azerbaijan" newspaper became a significant platform for the activism of Shafiga Khanum Efendizade. Shafiga Khanum was selected as a member of the editorial board of this newspaper. She wrote many valuable articles and stories about women's lives, struggles, rights, education, and enlightenment.

According to the statute adopted by the Azerbaijani parliament, women had the right to vote. Per the statute, consisting of four chapters and 116 paragraphs, all citizens of the Republic who reached the age of 20 could attend the elections to the Constituent Assembly. Intelligent Azerbaijani women using the rights granted and the conditions and opportunities created by the state for the development of enlightenment and culture were expanding the women's movement, and fighting against the forces that hindered the national liberation movement and the independence of the republic. Educated women were active in the creation of national schools during this period.

\section{Legal Acts Adopted by the Azerbaijan Democratic Republic 1918-1920}

The law on the "Political Amnesty" was discussed at the meetings of the Parliament of the ADR in December and was adopted at the meeting dated January 8, 1919. According to paragraph 5 of this law, penalties imposed by civilian and military authorities under the non-judicial proceedings, as well as the sentences given due to political insecurity until December 7, 1918, had been

\footnotetext{
${ }^{13}$ Cümhuriyyat parlamentinin yegana qadını - Mollaların tahdid etdiyi xanım kim idi?, 3.07.2018, http://modern.az/ az/news/146685\#gsc.tab=0, retrieved 7.09.2019.
} 
canceled and assignments related to the execution of those decisions had been given by the Ministry of Internal Affairs and the Ministry of Defense ${ }^{14}$.

Parliament had also adopted a series of laws to strengthen the material and social protection of certain strata of the population. Thus, in 1919 the laws "On improving the status of railway workers" and "On the provision of lumpsum aid to the employees of the Azerbaijani government organizations on the occasion of Novruz" were welcomed by the public ${ }^{15}$.

Despite its short lifespan, the ADR paid particular attention to the enlightenment of the population. The decision of the Parliament of the ADR on the approval of the Charter of the Baku State University on 29 April 1919 played an exceptional role in the development of Azerbaijani science and education. In this regard, the law "On the establishment of the Baku State University"16, adopted by the parliament on September 1, 1919, should be especially emphasized. The opening of the university was a significant historical service of the republic for the nation. Also, it is not accidental that 7 million rubles from the State Treasury were allocated to the Ministry of Public Education in the 1919-1920 academic year to send 100 students to Europe ${ }^{17}$.

The "Law on Azerbaijani Citizenship", adopted by parliament on August 11, 1919, was one of the laws of the ADR which had particular importance for legislative activity. According to Article 1 of the Law, despite national and religious differences, all the citizens of the former Russian Empire, themselves or their parents, born on the territory of the Republic of Azerbaijan were considered Azerbaijani citizens. Article 1 of Part 2 of the Law states that persons a) born to Azerbaijani citizens; b) foreign women married to Azerbaijanis; c) foreigners who adopted Azerbaijani citizens under the age of seventeen - not listed in the first article of the first part were entitled to citizenship of Azerbaijan ${ }^{18}$.

During its existence, the Azerbaijan Democratic Republic (ADR) also took successful steps in the field of military construction. The call up age for military enlistment was determined as 19 years.

The leaders of the republic did not forget to care for refugees and IDPs displaced from the native lands. Thus, the parliament adopted a special law "On Fulfilling the Refugee Needs".

By helping the Georgian people who suffered from the earthquake, Parliament adopted a law on allocating 3 million manats from the budget of the Department of Affairs of the government on March 11, $1920^{19}$.

\footnotetext{
${ }^{14}$ C. Nasirov, op. cit.

${ }^{15}$ Azərbaycan Xalq Cümhuriyyati dövründə hayata keçirilan sosial siyasat...; C. Nəsirov, op. cit.

${ }^{16}$ Y. Mahmudov, Encyclopedia of People's Republic of Azerbaijan..., p. 43.

${ }^{17}$ C. Nəsirov, op. cit.

${ }^{18} \mathrm{http}: / /$ www.azerbaijan-news.az/index.php?mod=3\&id=142726, retrieved 8.09.2019.

${ }^{19}$ C. Nəsirov, op. cit.
} 
To ensure the state's economic independence, the ADR also developed a series of laws in the field of customs, taking into account its importance. The laws adopted by the Parliament on January 18, 1920, "On the establishment of the border guard in customs relations in the Republic of Azerbaijan", and "On the establishment of Aghstafa customs post" are one of the significant legislative acts in the provision of customs service ${ }^{20}$.

During the period of its efficient work, the ADR also paid particular attention to the establishment of the justice, court, police and prosecution authorities of the independent republic. Khalil bey Khasmammadov was appointed first Minister of Justice. The activity of the Baku District Court and the prosecutor's office under it were restored by the decision of the Council of Ministers On October $1,1918^{21}$. It is no coincidence based on this date that it was decided to celebrate October 1 each year as a professional holiday for employees of the Prosecutor's Office of the Republic of Azerbaijan by the decree of national leader Heydar Aliyev dated July 17, 1998.

By the Decision of the Council of Ministers of the Azerbaijan Democratic Republic dated November 14, 1918, "The Statute of the Court Chamber of Azerbaijan" was approved. Here, Prosecutor and several deputy prosecutor positions were opened under Azerbaijan Chamber of Court ${ }^{22}$.

The Alliance of Independent States recognized the independence of Azerbaijan at the Paris Peace Conference on January 11, 1920. The political representation of the republic had already been functioning in France, Iran, Dagestan, Georgia, and other countries ${ }^{23}$.

A decision was made on the adoption of the Turkish language (Azerbaijani Turkish) as the state language on June 27, 1918. It was stated in the decision that until all courts, administrative and other officials learn this language, the Russian language is allowed to be used in government offices.

The ADR's leadership aimed to increase the share of the consumption fund in the gross domestic product, to increase the consumption fund, national income in GDP and employment levels per capita, to improve working conditions, to improve the level of education, health, housing and communal provision for the implementation of the state's social policy. However, the following factors made social conditions more complicated: the complicated international and domestic situation; economic difficulties; infectious diseases; arrival of more than 150,000 of our compatriots who were subjected to genocide of Armenians in the former Iravan province to Azerbaijan leaving their historical homelands;

\section{${ }^{20}$ Ibidem.}

${ }^{21}$ Ibidem.

${ }^{22}$ Ibidem.

${ }^{23}$ http://www.azerbaijan-news.az/index.php?mod=3\&id=142726, retrieved 8.09.2019; C. Nəsirov, op. cit. 
and undermining the land issue, which is the main factor in improving the living conditions of the villagers, who constitute the majority of the population, etc. The Parliament and the Government of the Azerbaijan Democratic Republic had taken urgent measures to eliminate social tension under such hard conditions $\mathbf{s}^{24}$.

The leaders of the republic did not forget to care for refugees and IDPs who were displaced from their native lands. Special attention was paid to the repayment of the material needs and deployment of refugees, the arrangement of medical services to them and other related issues. Thus, the parliament adopted a special law "On Meeting the Needs of Refugees". The decrees "On the Organization of Assistance to Refugees" dated July 13, 1918; "On sending a commission to the Shamakhi district to regulate the issue of the deployment of refugees" dated February 17, 1919; "On establishment of the Central Commission for clarifying the status of refugees and IDPs, their return to their permanent residence" dated June 23, 1919; "On Urgent Measures for the Placement of Refugees" dated November 8, 1919; and the Law of the Parliament "On Allocation of 21 Million Manats for the Needs of Refugees" issued on January 8, 1920 were one of the necessary steps taken in this area by the Government. Despite the difficult situation in the country, the government regularly assisted to our compatriots living in Georgia and Armenia.

During the activity of the ADR, a bill on various spheres was submitted to the parliament, and 10 of them covered the social field. Two major decisions were made on pension issues: one of them was "On the establishment of a commission for the preparation of the draft law on a pension" dated August 28, 1918. The decision intended the determination of the pension based on the years of service of the people who resigned. The Labor Exchange functioned in Baku during the Republic. The stock exchange was created on January 13, 1918, in the Baku City Duma ${ }^{25}$.

The government took several measures to increase salaries, allowances, formalize labor relations and so on, taking into account the hard physical work and the social status of the workers.

The Ministry of Labor was established to regulate labor relations, and other related issues in the Government of the ADR by the Decision of Parliament adopted on January 21, 1919. Obtaining executive and supervisory authority Ministry of Labor held a special meeting to improve labor protection and the living conditions of the workers on January 25, 1919. The ministry issued a decision to make some changes to the terms of the collective agreement on January $26^{26}$.

\footnotetext{
${ }^{24}$ Azarbaycan Respublikasl Jmək və Ohalinin Sosial Müdafiəsi Nazirliyi Tarixi, http://ses.gov. az/tarixi, retrieved 9.09.2019.

${ }^{25}$ Ibidem.

${ }^{26}$ Ibidem.
} 
The Government's activities were focused on the formulation of labor legislation, the regulation of relations between workers and entrepreneurs, and the protection of labor and the financial status of the working people. Specific decisions had been made to improve the social conditions of workers and servants.

The Azerbaijani government assisted those in difficult social conditions regardless of nationality. For example, in 1919, the government allocated substantial funds to the Russian and Jewish charity society, Armenian and Jewish national councils and other societies along with the Muslim women's charity society for the maintenance of children, the elderly and other groups, as well as to those affected by the earthquake that took place in Georgia in February 1920.

In 1919, the increase in allowances and wages in connection with inflation was the main priorities of the government's social policy. For this end, the Parliament adopted the Statute of the Ministry of Railways on the provision of railway workers after service years, as well as the laws on raising the salaries of government employees and elementary school teachers and increasing living standards. Several laws and decisions had been adopted to address refugee problems during the Fourth Government's activity.

The Labor Inspectorate under the Ministry of Labor was set up by the Council of Ministers to regulate labor protection, labor wages and labor disputes on August 5, 1919. A district inspector operated in each of the eight regions of the country. The decision of the ADR Parliament dated December 7, 1918, defines the payment of insurance to workers for full or partial loss of ability to work ${ }^{27}$.

The 1919 workforce program envisaged the protection of children and women's labor, the involvement of the administration in the work of the trade union organization, the suspension of attacks on worker's organizations, the freedom of assembly, and wage increases.

The ADR Parliament adopted decisions considering the social benefits of the concessional use of public utility services and transportation, increasing salaries and providing free financial assistance to refugees.

The issue of increasing the salaries of different sections of the population regarding inflation was an essential aspect of the ADR government's social policy. The Decrees (dated July 3, 1918, September 21 and October 13, 1919, April 10, 1919, and January 5, 1920) of the Government of the Republic intended to increase the salaries of government officials. For this purpose, Parliament adopted the law "On granting benefits to the servants" dated January 10, 1919; the law "On improvement of the state of railway workers" dated February 4; the law "On temporary increase of salaries of employees of the Ministry of Internal Affairs" dated April 7; the "Law on temporary additions to salaries of government employees" dated May 12 and the "Law on Additions to the

${ }^{27}$ Ibidem. 
salaries of civil servants in military and civilian government offices related to the expensiveness" dated March 15, $1920^{28}$.

The formation of labor legislation was one of the key issues in the government's social policy. At the request of the Labor Ministry, on March 10, 1919, the parliament adopted a law on the establishment of a special Advisory Board on the issue of workers under the Ministry. The Advisory Board dealt with issues of labor protection, and the regulation of relations between workers and entrepreneurs. The Advisory Board consisted of ten people - five workers and five entrepreneurs. The Board had the right to oversee the enforcement of laws applicable to all measures aimed at improving labor conditions and the financial situation of the workers ${ }^{29}$.

\section{New Culture Patterns Created by the Reforms Carried Out by the Government of the Azerbaijan Democratic Republic Have Become a Valuable Part of Azerbaijan's Rich Cultural Heritage}

Thus, there emerged favorable conditions to boost the revival of the cultural sphere arising from the enlightenment and renaissance in the country to a new peak with the establishment of the Azerbaijan Democratic Republic in 1918 in the late 19th and early 20th centuries. Culture and art were developed more freely and in line with national interests with the establishment of the national state.

It must be remembered that during the $\mathrm{ADR}$, national societies such as the "Türk Ocağı" ["Turkish Hearth"] Society, whose aim was to propagate ideas of Turkicism and Azerbaijanism among the population, were established in Azerbaijan.

At the same time, the "Muslim East Learning Society", founded on December 29, 1919, also paid great attention to the study of the medieval cultural monuments of Azerbaijan. This organization mounted exhibitions based on the learned materials, which enhanced the interest of our people in their historical past, strengthening their sense of patriotism ${ }^{30}$.

As is known from the historical materials, the Government of the ADR had also done considerable work to establish museums in our country: for example, "Istiglal" Museum [the Museum of Independence], one of the significant events in the history of our culture, represents the memory of that era. This cultural institution is the first state museum to demonstrate and promote the history and culture of Azerbaijan, its national and artistic heritage. The museum

\footnotetext{
${ }^{28}$ Ibidem.

${ }^{29}$ Azarbaycan Xalq Cümhuriyyati dövründa hayata keçirilan sosial siyasat, "Hərbi And", 13.04.2018, No. 14, p. 6, http://www.elibrary.az/docs/qazet/qzt2018_1864.htm, retrieved 9.09.2019.

${ }^{30}$ N. Bayraml, Xalq Cümhuriyyati hökumətinin həyata keçirdiyi islahatlar mədəniyyatin ayr-ayrl sahəlarinin inkişafina təkan verdi, "Yeni Azərbaycan”, 10.04.2018, No. 68, p. 3.
} 
was opened on the occasion of the anniversary of the Azerbaijani Parliament on December 7, 1919, and operated under the parliament in its building ${ }^{31}$.

Special attention was paid to the development of national painting during the ADR as well. Thus, "Zanbur" magazine published caricatures referring to the social and political problems of the time which were created by Azim Azimzade, the founder of Azerbaijani satirical drawing in 1919. His paintings exposed darkness, ignorance, and the wild and disgusting acts of bloodthirsty Armenian-dashnak robbers. This theme had a significant place in the work of the artist Bahruz Kangarli ${ }^{32}$. His famous series "Refugees" reflecting on the Armenian-Muslim conflict, was an achievement of realistic Azerbaijani art.

The foundation of the ADR also triggered the revival of the national theater. Significant qualitative changes took place in the development of the Azerbaijani theater as a result of the active support of the state. New works on the history of Azerbaijan and the struggle for national liberation entered the repertoire of the theater. The role of theater in social life increased. The first troupe to restore its activity in the Republic was "Hajibeyli brothers". Troupes bringing together famous artists performed drama, comedy, opera, and operetta in turn.

The opening and subsequent activities of the Azerbaijan State Theater were one of the brightest pages of cultural life during the People's Republic. The curtains of the State Theater opened for the first time on November 4, 1918, with the performance of Nariman Narimanov's Nadir Shah tragedy. Charity performances were also organized at the theater building.

The Azerbaijani Anthem, created by composer Uzeyir Hajibeyli and poet Ahmed Javad in 1919, and the National Anthem of the Republic of Azerbaijan today, constitutes an excellent example of our national music.

The Azerbaijan Democratic Republic has left indelible marks on the history, political and spiritual-psychological life of the Azerbaijani people, including the literary and artistic works of the period. The achievement of the independence of the Azerbaijani people caused a great revival in the artistic environment.

Thus, given those mentioned above, we can say that the period of the ADR was engraved in history with the rise of different spheres of Azerbaijani culture and art. The new material and spiritual cultural samples which were created during this period have become a valuable part of Azerbaijan's rich cultural heritage.

\section{Summary}

The Azerbaijan Democratic Republic, the first Parliamentary republic in the history of the Azerbaijani people, was the first democratic, legal and secular state in the East, including the Turkish-Islamic world.

\footnotetext{
${ }^{31}$ Ibidem.

${ }^{32}$ Azarbaycan Xalq Cumhuriyyati dövründə madani inkişaf, “Olaylar”, 25.05.2018, p. 8, http:// www.anl.az/down/meqale/olaylar/2018/may/592731.htm, retrieved 7.09.2019.
} 
The Democratic ADR was part of the democratic republics of Europe for its political structure, its democratic state-building measures, as well as its goals and objectives.

The ADR, which operated for a total of 23 months, left indelible marks on the history of national statehood with its rich state-building experience, and built a solid foundation for the future independence of the republic by strengthening the feelings of freedom and independence in the hearts of the people. Thus, the Government of the ADR operated in Tbilisi for 18 days, about three months in Ganja, and less than 19 months in Baku.

The ADR was able to make profound changes in all spheres during its activity, and served the interests of the people. Within a short period, the Republican Government underwent fundamental reforms covering various areas of society, thereby establishing a sustainable development process in the country. The prominent intellectuals and social-political figures of Azerbaijan were always at the forefront of this process. And their initiative, determination, and intellectual level created enormous opportunities for the successful implementation of these reforms.

Even though it operated under very complicated conditions, the Government and the Parliament of the Republic kept the focus on the development of science, education and public education, and health care. Schools, gymnasiums, girls' schools, kindergartens, libraries were opened in the whole country, short-term teacher courses, hospitals, and medical assistant points were established in rural areas, and the fight against infectious diseases was put into action.

In 1991, the Azerbaijani nation restored its state independence and created a new independent state of Azerbaijan, which continues the ideals of the Azerbaijan Democratic Republic in terms of historical heritage.

Azerbaijan is one of the few countries to have declared its democratic values a hundred years ago and to have put them into practice. Today's independent Azerbaijan is the successor to the Azerbaijan Democratic Republic ${ }^{33}$.

The revival of the lost national statehood at the end of the twentieth century confirmed the national-liberty spirit of our people in the confusion that exacerbated the historical conditions in 1920. In 1991, Azerbaijan proclaimed its independence for the second time. The adoption of the Constitutional Act on the State Independence of the Republic of Azerbaijan on October 18 was the beginning of a new stage in the history of the Azerbaijani people.

Today, President Ilham Aliyev strives to consolidate and develop Azerbaijan as an independent country, and to build a democratic and legal state, remaining true to heritage traditions. The main purpose of this policy is to raise the mate-

\footnotetext{
${ }^{33}$ Speech of the President of Azerbaijan Ilham Aliyev on the People's Republic of Azerbaijan.
} 
rial well-being of the society and individual citizens separately, and to provide them with social protection and a decent standard of living, as well as equal opportunities for the free development of personality. In general, the policy pursued by Azerbaijan is a guarantee that Azerbaijan is a fully independent republic in the region. 